\title{
TAP ROOTS OF IOWA AGRICULTURE
}

\author{
By EarL D. Ross
}

To paraphrase Emerson's sententious sentiment regarding America and opportunity, "Iowa" may be said to have been through the years and still to be another word for agriculture. This fact was recognized by the state's founding fathers and has been abundantly verified throughout the changes of the most changeful of centuries.

The First General Assembly in special session in 1848, in petitioning congress for the gift of Fort Atkinson for use as an agricultural college, made the plea on the premise that agriculture was "the leading interest in this state." The state's first governor, Ansel Briggs, advanced the same assumption in his second message in 1850: "The best method of cultivating the soil is, and it is believed ever will be, a subject of the first importance to a large majority of the citizens of the State." This sentiment was to be reiterated by his successors and other spokesmen for the state's economic prospects.

In his appeal to prospective settlers, in 1870 , as secretary of the State Board of Immigration, Alexander R. Fulton made the opportunity for farming the great inducement (Iowa: The Home for Immigrants): "Iowa is peculiarly an agricultural state. Whatever inducements she may at present, or in the future, offer to the manufacturer, the miner, or persons engaged in the other pursuits in life, the essential fact remains, that the true source of her rising greatness and prospective grandeur lies in the capacity of her soil to supply those staples absolutely necessary for the sustenance of man."

Governor William Larrabee, who could speak from unusually long and large personal experience, summed up the matter in the hectic days of the latter eighties: 
"Agriculture 1s our chief interest. If it languishes all other interests suffer."

Ten years later Leslie M. Shaw in assuming the duties of chief executive amid more hopeful conditions put the matter with characteristic raciness: "Iowa is an agricultural state and will remain one. Not exclusively agricultural, but predominately so. Of this fact we are assured, and with it we are content."

It remained for Governor Cummins in the age of the new industrialism to give the sentiment finality: "We hope for diversification in our industries, but we know that agriculture will always be our paramount interest."

Convincing evidence of the practical reality of these assertions is to be found in the part that Hawkeye farmers have had in the making of the modern diversified farming enterprise, technically, managerially, and socially. In mechanization of farm and home, in improved methods of cultivation and husbandry, in the achievements of plant and animal breeding, as well as in cooperative and other organized activities, the state has been in the vanguard when not at the very head of the procession. As a cause and accompaniment of these achievements, Iowa has contributed to the profession a remarkable number of investigators and administrators, including, to date, four of the twelve secretaries of agriculture.

In turn the high points in the making of the state as a whole have been related directly to the great and basic interest-the squatting on border clearings and the pioneer trading in river settlements, the invasion and utilization of the prairie, the Civil war and expanded and disorganized economy, railroad extension, and the settlement of the last frontier area in the northwest, the transition to a "corn belt" economy, and the adjustment to the new industrialism and world conflict. In short, the emergence of a great modern commonwealth may be traced in the changes from frontier truck patch and cabin to modern farmstead, from cradle to combine, from primitive hand operations by rule of thumb to 
"technology on the farm." "The history of Iowa agriculture," it has been said, "is the history of Iowa."(Wallace's Farmer and Iowa Homestead, September 7, 1940).

\section{FARM Life Dominant}

To the observer and participant of the present the dominant place of her farms in the state's life and work and their absolute and relative achievement are everyday experiences. Tall corn and other products of field and fold are not just tall tales. This state in her folklore has needed no legendary figures to express the demonstrated productivity. The celebrated elongated hog that stretches from pole to gulf is but a graphic statistical summary. However, to believe in such progressive attainments amid the small beginnings and simple ways of the mid-nineteenth century required the faith and vision of the pioneer. Few contrasts could be more striking than the faces of the prairie landscape then and now-even without the added intensities of global war. Yet related they are by the continuous thread of historical sequence, and we may well consider, in our centennial retrospections, what the main forces have been in this stupendous growth and transformation; the tap roots, so to speak, of Corn Belt economy. And, as always in history, the determining influences are to be found in the basic factors: the place, the period, and the people.

Physically the "Iowa country" was uniquely blessed. "Providence has been good to us," declared President R. A. Pearson of Iowa State College, and nature's beneficence has here been manifested through the years in times of good report and those not so good. Among the world's agricultural areas the Prairie Plains are assigned a most favored position, both as regards productivity and accessibility. The phrases "garden spot of the continent" and "bread basket and meat-platter of the nation" are not mere figures of speech. They have been abundantly verified in supplying the needs of a highly industrialized nation and in providing the rations for three 
major wars. In the "heart of the Corn Belt" Iowa has occupied the most congenial portion of the realm of King Corn, with by far the highest proportion of effective farm acreage and a quarter of the total grade $A$ land of the nation. As Egypt was called the gift of the Nile, so Iowa might be termed the gift of the glaciers in their most benevolent mood; and nature does not duplicate her masterworks.

The occupying of such a landfall was facilitated by situation between the main waterways of the interior basin in the central line of movement across the continent. The admission of the trans-Mississippi Hawkeye state two years before the Badger from the Old Northwest is an evidence of the strategy of location, as in the contrast with the formative development of Arkansas which attained the dignity of statehood a full decade before the "first free state" of the great purchase. In the successive stages of the development of a national system of transportation, flatboat, covered wagon, transcontinental railways, highways, and airways, the state's situation has been of continuous and ever-increasing significance. In a time of social ferment at home and abroad, with such an unparalleled opportunity in availability and accessibility as the "new purchases" presented, Greeley might well have "meant Iowa."

\section{Formative Soctal Development}

No less fortunate than the physical setting was the social, the times in which the formative developments were made, both for what had gone before and for the attending conditions. Much had already been ventured and achieved in pioneering when the institutions and economy of the pioneer state were being formed; older frontiers had labored at great cost and sacrifice and the younger was able to enter into their labors in experience, leadership, and improved facilities for production and distribution. To be sure the attainments of the years have not been without trials of nature-storms, pests, 
plant and animal diseases-and the still more retarding and disrupting social maladjustments.

All the same, the cruder, harsher conditions of pioneering had stopped short of the Middle Border and the youthful nation, as a whole, had passed through the worst of its growing pains. By the time the new commonwealth was becoming adjusted to its new dignities and responsibilities and before she had secured a revised constitution and a permanent capitol, the nation, in its political and social strivings, had passed from the agitating thirties and the aspiring forties to the achieving fifties. Territorially the nation was realizing her continental manifest destiny. The railroad having demonstrated its local utility was building steadily westward and was being paralleled by the great communication adjunct, the magnetic telegraph. The home market was becoming systematized and foreign commerce was reaching unprecedented heights. The factory system was dominant in manufacturing. Farming was undergoing a "transformation" comparable to that in industry. With the economic changes went a zeal for social reform and intellectual improvement. In all of these strivings for a new economy and a new society, the twenty-ninth state shared, as she did all too soon in her career in the strain and test of sectional conflict. It was an opportune and crucial time in which to be born, for an individual and for a state.

This conjunction of available land and of social unrest and aspiration brought not only a great rush of settlers in the formative decades but a relatively select migration. As on all frontiers there were restless and aimless wanderers, hunters and trappers, speculators and varied sorts of adventurers. But the proportion of permanent settlers, of home and community builders was unusually large, and in origins and economic and social status no state has had a more typically American population. The whole was leavened by alert innovators who brought the improved practices of their respective regions to the favored environment, as well as moral and intellectual 
reformers who sought the promotion of institutions, of religion, and the means of education. Notable examples were pioneer horticulturists from New England and New York, stockmen from Ohio and Kentucky, dairymen from New York and Pennsylvania, and the bands of religious and educational missionaries.

The resulting economy and society were no less typically American, according to the best traditions. The Jeffersonian ideal of predominant and diffused independent proprietorship found perhaps its fullest realization. A liberalized stability - that to impatient radicals might seem decadent conservatism-was the logical characteristic of such a society.

To be sure, the favored land and its favored people were not free from frontier abuses. There were land engrossment, speculative manipulation, and corrupt political collusion. But such sensational episodes can readily be exaggerated; they were not as common or as determining as often represented. Large scale cropping was not as prevalent or as extreme as on older frontiers; and the comparatively few early corporate enterprises did not persist. The typical undertakings were family farms in size, capital, and operation. There was always a recognized practice of community cooperation, but the initiative was strictly individual.

\section{PIONEER METhodS SUPPLANTEd}

Such an economy overcame pioneer limitations, survived the disorganizing demands of civil strife, and endured the hard times of the eighties and nineties better than most production areas. It also made effective adjustment to the earlier stages of the new scientific and mechanized agriculture as demonstrated by its production capacity in World War I.

The imperative and stupendous demands upon the food producers of that titanic struggle-second only to its global successor-brought to a culmination problems of the new industrialism and capitalism that had been 
long cumulating: tenancy, credit, conservation, inflated land values, the surplus. In dealing with the resulting conditions, both emergency and long-time, new types and degrees of voluntary association and of social control and direction were entered upon here as in other farming belts.

These new organizations, programs, and controls have seemed at times to offer a direct challenge to the old basic traditions of mid-America. Indeed not a few defenders of the old system, considering outward forms more than inner spirit and measures of emergency relief rather than those of permanent improvement, have insisted that the landmarks of the fathers were fast "vanishing."

Assuredly, patterns have been strangely altered and concessions made "for the emergency" at least until to the casual or biased view it may appear that the break with the old days and ways is complete. Any such conclusion, however, is without reasoned justification; it is always unsafe to accept temporary surface indications as a conclusive evidence of change from long-established practices and attitudes, especially when these systems and folkways are founded upon basic "natural" conditions. On the contrary, as recurring protests against too marked departures serve notice, traditions and convictions so established have a stubborn persistence.

However contrasting in outward form, the spirit of "the state of the tall corn" maintains unbroken continuity with the past through the vitalizing influences that have provided her unique characteristics. So to appreciate current reactions and to forecast future tendencies, one must ever bear in mind the enduring natural resources of the Prairie Plains at their best, the "age of the common man" in which the commonwealth was born, and the nuclear population of old-stock middle-class landowners. 
Copyright of Annals of Iowa is the property of State of Iowa, by \& through the State Historical Society of Iowa and its content may not be copied or emailed to multiple sites or posted to a listserv without the copyright holder's express written permission. However, users may print, download, or email articles for individual use. 